\title{
Kinds of Metaphor in Hasan Tiro Speech
}

\author{
Tasnim Lubis \\ Politeknik LP3i Medan \\ tasnimlubis@yahoo.com
}

Keywords: Metaphor; speech; Hasan Tiro.

\begin{abstract}
Metaphor is used in speech toward the message delivery. It is able to grab many sentences into a word, an expression, a proverb, etc. There are four kinds of metaphor proposed by Kovecses, they are conventional metaphor, cognitive function metaphor (consist of structural metaphor, ontological metaphor and oriental metaphor), nature of metaphor, levels of generality of metaphor. The objectives of this study were to investigate kinds of metaphor in Hasan Tiro speech. Qualitative research was applied. The data were written texts (document) of his speech entitled Sumatera Siapa Punya I (who belong Sumatera I) and Sumatera Siapa Punya II (who belong Sumatera II). They were analyzed by using Miles and Huberman analysis. The analysis consists of data selection, data display, and verifying/conclusion. The result of the study displayed that there were two kinds of metaphors, they were conventional metaphor and ontological metaphor. The dominant was conventional metaphor. It occured because it related to daily usage and indexicality.
\end{abstract}

\section{INTRODUCTION}

The main goal of communication is to deliver a message. People speak literally and pragmatically. That is why language are fascionated, unique and interesting to study. Language has power when the speaker produced it (both orally or writtenly) is understood and achieved by the listener. The adequate proverb, expression, even word as part of metaphor, has important role in delivering mesagges. Metaphor consists of two words, they are meta and phoric. Meta means half and phoric means refer to something.

Therefore metaphor can be defined as understanding two entities based on similarity. In common, metaphor is a figure of speech in which one thing is compared with another by saying that one is the other, as in He is a lion. Lakoff and Johnson (2003) state that "Metaphor is for most people a device of the poetic imagination and the rhetorical flourish a matter of extraordinary rather than ordinary language". They also explain that metaphor is typically viewed as characteristic of language alone, a matter of words rather than thought or action. For this reason, most people think they can get along perfectly well without metaphor.

One way to deliver the speakers' message is through speech. Speech deals with persuade the listeners or the voters to understand and follow the speakers want. Speech has power if the speakers use metaphors that indexes to the listeners' knowledge. Lubis (2017) states that the meaning of a sign (in this case speech), that achhieved by individual is rely on his/her knowledge, memory, and understandable in its language.

Formerly, studying metaphor was common in literary works, such as novel, play, and poetry. Generally, people know that such metaphors are common and important in literature. But, in fact, we live by metaphors. In Indonesia, we named sun as matahari. Matahari consist of two words, mata (eye) and hari (day). Indonesian do not realize it is metaphor instead of a name. That is why I agree with Lakoff and Johnson' concept about metaphor by saying metaphor we live by. Lakoff and Johnson (2003) view of metaphor claiming that (1) metaphor is a property of concepts, and not of words; (2) the function of metaphor is to better understand certain concepts, and not just some artistic or esthetic purpose; (3) metaphor is often not based on similarity; (4) metaphor is used effortlessly in everyday life by ordinary people, not just by special talented people; and (5) metaphor, far from being a superfluous though pleasing linguistic ornament, is an inevitable process of human though and reasoning. 
Speech for leaders concern to deliver the message to the listeners or followers. Often, they use expression with rich metaphor to build the power of their speech. On the other hand, listener should grasp and gain the understanding. Using of metaphor is also influenced by ideology, culture and situation of the speakers. In addition,it is used to get the audience understanding and persuade them to do as what the speakers say. Not only to persuade but also to provoke the audiences.

The objective of this study was to find out kinds of metaphor which is used by Hasan Tiro in his speech. Hasan Tiro was a phenomenal leader in Aceh. He was popular of his revolution namely GAM (Gerakan Aceh Merdeka). He declared Aceh independent day on December 4th 1976. He attracted people attention not only in Indonesia but also in the world. The use of metaphor in the text of his speech has given the power for his community even though he was in abroad (Sweden). One of his speeches that contain the metaphor can be seen as follows:

Saya panggil semua pemuda-pemuda Sumatra supaya berpegang tangan dengan pemudapemuda Acheh Merdeka untuk memerdekakan Tanah Pusaka kita bersama dari cengkraman bandit-bandit Jawa dan kaki tangan mereka. Jangan hormati mereka itu lagi, sebab menghormati mereka berarti menunjang mereka! Menghormati mereka berarti menghina diri-sendiri!

(I call you, all of Sumatra young generation to holding hands together with Aceh Merdeka to set our inheritance free from Javanese criminals and their supporter. Do not respect them anymore, because respect them means losing our prestige!)

The use of word "holding hands" in the text has been given the power to him to build confidence and spirit for the audience to be brave in their revolution. He persuaded all Sumatera people to join with GAM and make them sure that their togetherness will make them stronger. Hasan Tiro was able to persuade people especially Acehnese to follow his order. He spent a lot of his time in Sweden because this country protected him from Indonesian government chased. As a revolutionary, he was well known as figure that had skill and style in conveying a good speech in front of his followers. As a leader, his speech was able to build patriotism with his followers. As the evidence, at this time, almost area in Aceh has been leading by Aceh party.

Hasan Tiro used metaphor in his speech to build Sumatera people sympathize so they would follow what he said. Consequently, they would like to join with GAM in order to get the independence and free from Java goverment. The way of he produce metaphor to conceptualize nation, his revolution and opposition related to his social context.

\section{METHOD}

The data of this study was taken from text of Hasan Tiro speech entitled Sumatera Siapa Punya I and Sumatera Siapa Punya II. The text was given by Hasan Tiro's nephew namely Musanna Tiro. The data were analyzed by using Miles and Huberman data analysis that consist of data selection, data display, and verification/conclusion. Kinds of metaphor rely on Kovecses (2010) theory.

The data in this research were words in Hasan Tiro speech text. Bogdan and Biklen (1992) says that people's own words is included a data in Qualitative Research. Sumatera Siapa Punya speech was taken from February 1, 1991. In analyzing the data, the procedure was (1) Identifying the data that are needed for this research, (2) Classifying the data based on the metaphor in pragmatic (3) analyzing the data based on the theory that is used. In selecting and identifying the data, I used the procedure of identification metaphor is known as MIP (Metaphor Identification Procedure) by Praglejazz Group (2007).

\section{FINDINGS AND DISCUSSION}

In cognitive view, metaphor deals with though and reason rather than linguistic expression. Lakoff and Johnson (2003) argue that metaphor is defined as understanding one conceptual domain in terms of another conceptual domain. As understanding the pattern of understanding one conceptual to another, Lakoff and Johnson (2003) divided two conceptual domain into source domain and target domain.

Hasan Tiro used a lot of metaphor in his speech, especially when he wanted to express the nation, his struggle, and the enemy. Based on Kovecses (2010) consept, he divides metaphor into four, they are conventionality of metaphor, cognitive function of metaphor (consisit of three parts; structural metaphors, ontological metaphors, and oriental metaphors), the nature of metaphor and level of generality of metaphor. Conventionality of metaphor concerns to 
manifestations. The metaphors, both conceptual and linguistic, are conventionalized, in that speakers of English use them naturally and effortlessly for their normal, everyday purposes when they talk about such concepts as argument, love, social organizations, life, and so on. For example: argument is war means I defended my argument. In this case, Hasan Tiro used this kind to express his struggle. It can be seen as belows:

- Saya sudah datang untuk mengunjungi Saudara-saudara sekalian, dan masingmasing, dimana saja Saudara-saudara berada: di rumah, di kantor, di pasar, atas Tanah ibu Sumatera, atau di perantauan. (I've come to visit you wherever you are: at home, at the office, at the market on mother land Sumatera or in overseas). Mother land refers to Sumatera. Source domain was human. It means someone who make a birth. Hasan Tiro used this to build togetherness with his followers and audiences.

- bahwa penjajahan bandit-bandit Jawa dari Jakarta yang sudah terjadi selama 46 tahun yang akhir-akhir ini tidak dapat menghapuskan Sejarah Negara Acheh Merdeka yang sudah lebih 1000 tahun itu, dan diakui oleh dunia! 46 tahun penjajahan bandit-bandit Jawa tidak mungkin dapat menghapuskan 1000 tahun Sejarah Acheh Merdeka! Dan Sejarah Acheh Merdeka sama dengan Sejarah Sumatera Mardeka! (the Javanese criminals imperialism whom belong from Jakarta even 46th years can not delete the history of Aceh merdeka that had been stood for over 1000 years, and the world knew it. The 46th years were not able to delete the history of Aceh merdeka for over 1000 years. The history of Aceh merdeka as long as the history of Sumatera merdeka) Litrerally, delete means remove something written. Metaphorically, delete refer to action of disappearing the history by Javanese criminals. Source domain for describing the phenomenon was movement. The concept is Aceh history can not be erased. The concept is Aceh was up. It is include in conventional metaphor)

Cognitive function of metaphor uses for the purposes of a clearer exposition, conceptual metaphors can be classified according to the cognitive functions that they perform.

Ontological metaphor provides much less cognitive structuring for target concepts than structural ones do. Ontological metaphor were used to show the similarites between two entities. It is deals with personification. For examlpe:

- Setiap anak Sumatera mempunyai berat yang menentukan dalam neraca saya.(Every Sumatera's children have a weight in my scales). Weight literally is something which can be measured. Metaphorically, weight refers to the potency of Sumatera people in his revolution. The concept is Sumatera people is potency.

- Setiap anak Sumatera mempunyai berat yang menentukan dalam neraca saya. Scale is range or levels or numbers use for measuring something. Metaphorically, scale refers to Hasan Tiro's calculation. The concept is Sumatera people is potency.

- Saudara-saudara bukan hanya satu angka yang tidak berarti apa-apa dalam statistic (Ladies and gentlements, you're not only a number in statistic) Literally, a number means symbol or word representing quantity. Metaphorically, a number refers to the existence of Sumatera people who has potency to support his revolution.

Statistic is information shown numbers. Hasan Tiro use this term in order to describe a group of Sumatera people. The concept is Sumatera people is potency.

Based on data collection, kinds of metaphor in Hasan Tiro speech only exist in were conventional metaphor and ontological metaphor.

Metaphor deals with understanding one concept into another concept. Generally, the concept is drawn because of some similarities. But in cognitive view as in Lakoff and Johnson theory, metaphor is property of concept rather than words expression. The way of someone in produce metaphor is influenced by s/he social context. For example, one reporter said that, "jalan-jalan arteri di Jakarta tergenang banjir". The other repoter said that, "ruas-ruas jalan protokol di Jakarta tergenang banjir". The usage phrase of jalan-jalan arteri and ruas-ruas jalan protokol refer to the main street. But the concept of the speaker in produce the utterances are different. The first reporter use part of body as source domain, meanwhile the second reporter use plant as source domain.

In political speech of Hasan Tiro, metaphors were used to persuade the followers and audiences in order to join in his struggle. He attracted their attention by using conventional metaphor and ontological metaphor because he knew already the audiences. He used word pemuda (young 
generation) to attract the attention of young generation who had been bad experiences such as losing their family because of his enemy (in this case, he mention as javanese bandits). In addition, he also wanted to describe how the enemy treated Acehnese. He also used the word anak (children) to emphasize that the struggle was for good.

$\mathrm{He}$ is one phenomenal leader in Aceh proved that he had so many followers. He has power in each his speeches. Metaphor is used in order to wrap on the important message in his speech as belows:

Geutanjoë Atjèh na saboh bansa ateuëh rhuëng dônja lagèe bansa-bansa laén tjit: geutanjoë na Nanggroë droëteuh: nanggrö̈ Atjèh; geutanjö̈ na basa drö̈teuh: basa Atjèh, geutanjö̈ na riwajat droëteuh: seudjarah Atjèh, njang ka geupeugot lé éndatu teuh. Njoëkeuh pusaka njang handjeuët sagai tatuwo, urö̈ dan malam, beungoh-seupot, pat njang ta duëk, bôh bak gaki Seulawah, bôh bak putjak Geureudông. bôh bak binèh Kuta Aneuk Galông, bôh di Iërupa atawa di Amérika. Nanggro Atjèh njö̈ na keuh ibarat saboh kuta raja, njang ka geupeudong lé éndatu geutanjö̈ turônteumurôn meuribèe thôn njang ka u likôt keu teumpat hudép, keu teumpat maté, dan keu teumpat meuneu'èn geutanjö̈ aneuk-tjutjo geuh.(quoted from Hasan Tiro's book Atjeh di mata Donja)

The meaning is Aceh is a nation in this world. Like the others nation, we have our own name, it is Aceh, our own language, it is Acehnese, our own history, it is Acehnese history that belong to our ancient. This is our heritance which should be keeped in nights and days, in the morning and the evening, wherever we are, even in leg of Seulawah Mountain, even on top of a tower, even in Kuta Aneuk Galông, even in Europe or even in America. Aceh is like Kutaraja (Soultan), that was built by ancient for thousand years ago. It is the place where we live, we die and belong for our generations.

He wanted to remind Acehnese about who they are, what they are and where they belong to. Hasan Tiro conceptualized his nation as motherland, fatherland and golden island. He conceptualized his revolution through war and involved UN Committee to show that he able to lead because he had good strategy in war and also diplomatic. He also conceptualized the opposition as animals, criminal, job, toy and human body.

Hasan Tiro used nine source domains in his speech. Based on Kovecses theory, there are thirteen source domains of metaphors. Hasan Tiro used economics source domain dominantly to wrap out his point in his speech that maintain Sumatera property. Besides, he used the rest of metaphors to support his information that convey his revolution. For instance he used metaphor light to inform about Aceh history in the past which delighted and had power. To contrast the situation, he used source domain dark for the opposite situation.

Hasan Tiro conceptualized his nation as motherland and fatherland because he wanted to deliver his concept that nation refer to the parents that should be take care. In Acehnese, the word motherland or fatherland as same as tanoh endatu. Tanoh endatu means the heritage for Acehnese people which a gift from God hence should be protected and maintained from the other nation. This statement can be seen in his speech, "Bangsabangsa, pulau-pulau, benua-benua, adalah kenyataan-kenyataan alam, bikinan Tuhan, yang tidak dapat dibuat-buat, atau dibikin-bikin oleh manusia... (Nations, islands, continents are the evidence of nature, the creation of God, it is impossible made by human...). Moreover, he conceptualized the nation as an golden island. It refer to one of Acehnese famous mines is gold. Therefore, he also wanted to express the target domain for nation. Comparing with Moreno (2008) study about Chavez who conceptualized the nation as a person who has been resurrected by his government, as a person ready to fight for his revolution, or as Chavez's himself. The different finding occurred because someone's concept is related to his/her social context which covered culture, situation and ideology. Saragih (2004) says that social context is constituted by ideology, culture, and situation.

Hasan Tiro conceptualized his opposition as criminals, animals, human body, toy and job, meanwhile Moreno (2008) found that Chavez conceptualized his opposition as war combatants or criminals. He used source domain human body (leg and hand), toy (doll), criminal (bandit), animal (dog), and job (clerk) to describe the enemy and plant it into his followers mind. Lakoff and Johnson (2003) stated that one's/groups" experience of physical objects and substances provides a further basis for understanding one that goes beyond mere orientation. Understanding experiences in terms of objects and substances allows them to pick out parts of their experience and treat them as discrete entities or substances of a uniform kind. Once we can identify our experiences as entities or substances, we can refer 
to them, categorize them, group them, and quantify them and, by this means, reason about them.

Conventional metaphors were used by Hasan Tiro to make the audience easy to understand his intension. Duranti (2016) explained that intension is the central of philisophy of language. Then, ontological metaphors were used to explain the concept of Hasan Tiro perspective therefore the audiences understand his thought and ideas. There was similiarity study about kind metaphor which is used by Acehnese in hikayat (such a poetry) Aceh entitled Hikayat Ranto and Teungku di Meukek. Lubis (2016) found that both hikayats use experiential similiarity as their metaphorical concept. The choice of source domain related to the language concept that covered the pattern and meaning hence the types of metaphor in Hikayat Ranto and Hikayat Teungku di Meukek were Conventional and Ontological metaphors.

Marpaung (2011) found that Barack Obama used metaphor in his speech to describe and explain his concept about responsibility, leadership, and patriotism and liberalism value to wrap on his commitment. He analyzed that Barack Obama used conventional metaphor, mixed metaphor and poetic metaphor.

In this study, based on his speech in Sumatera Siapa Punya, conventional metaphor was dominant rather that ontological metaphor. It is appeared because conventional metaphors are used in daily conversation, hence by using them, the audiences with different level would understand the speaker's intension.

The percentage of kind metaphors can be displayed in table below:

Table 1. Percentage Types of Metaphors in Hasan Tiro' Speech

\begin{tabular}{|l|l|c|c|}
\hline No & Types of Metaphors & Number & Percentage (\%) \\
\hline 1 & $\begin{array}{l}\text { Conventional } \\
\text { metaphor }\end{array}$ & 35 & $85.36 \%$ \\
\hline 2 & $\begin{array}{l}\text { Ontological } \\
\text { metaphor }\end{array}$ & 16 & $39.02 \%$ \\
\hline & \multicolumn{1}{|c|}{ Total number } & 41 & $100 \%$ \\
\hline
\end{tabular}

Based on the analysis, Hasan Tiro only used Conventional metaphor and Ontological metaphor in his speech. From the table above, Conventional metaphor $(85.36 \%)$ is dominantly rather than Ontological metaphor (39.12\%). Conventional metaphors are used by Hasan Tiro to convey his concept and can be understood by the audience/listener. Conventional deals with the same notion about something but different to express it. Kovecses (2010) states that the use of the notion of conventionality is different from the way this concept is usually used in linguistics, semiotics, and the philosophy of language. The typical application of the term in these fields is synonymous with that of the term "arbitrary," especially as this is used in explaining the nature of linguistic signs (where it is pointed out that "form" and "meaning" are related to each other in an arbitrary fashion). However, the term "conventional" is used here in the sense of well established and well entrenched. There are conventional ways of talking about the same domains. For example the enemy should roll the mattress refers to out of business. The metaphor roll the matress hs the same meaning to gulung tikar in Bahasa. Hasan Tiro used this kind in order to explain his concept about his revolution. The metaphor that he used are common to Sumatera people, therefore they were able to understand Hasan Tiro's intension. Conventional are used in order to persuade the Sumatera people to maintain the Sumatera property and to pursue the opposition from Sumatera.

Ontological metaphor as part of cognitive function is used for ordinary people in thinking about and seeing the world. The purpose is to provide exposisition clearly. Ontological metaphor deals with personification. Ontological metaphors provide comparison between things that delivered by Hasan Tiro to describ one concept to understand the other concept. It clearly can be seen when he conceptualized his oppositions. He describe them as animals, tool, human body and criminals. From the personification, he believed that the audience would get the meaning of the opposition clearly.

The finding of this study would be presented based on the analysis of source domain, conceptualization of nation, revolution and opposition and kinds of metaphors were used by Hasan Tiro. The finding formulated as follows:

- Hasan Tiro used nine source domain, they are economic, plants, human body, light and darkness, movement and direction, tools, animals, healthy and building/construction.

- Hasan Tiro used source domain economics dominantly than the others source domain

- Hasan Tiro conceptualized his nation as motherland, fatherland and golden island.

- Hasan Tiro conceptualized his revolution through war and involved UN Committee

- Hasan Tiro conceptualized the opposition as animals, criminal, job, toy and human body

- Hasan Tiro used Conventional metaphor and Ontological metaphor in his speech. 
Newmark (1988) classified metaphor into Dead Metaphor and Live Metaphor. Dead metaphor refers to those expressions with conventional rhetorical usage of language, whose existence can hardly be sensed when we hear or read them. Some examples examples include mouth of the river and leg of a table. Live metaphor means those expressions temporarily created by authors or speakers which can inspire readers' or audiences' rich imagination.

Kovecses (2010) divides metaphor into four, they are conventionality of metaphor, cognitive function of metaphor (there are three parts; structural metaphors, ontological metaphors, and oriental metaphors), the nature of metaphor and level of generality of metaphor. Conceptual metaphors concerns to manifestations. The metaphors, both conceptual and linguistic, are conventionalized, in that speakers of English use them naturally and effortlessly for their normal, everyday purposes when they talk about such concepts as argument, love, social organizations, life, and so on.

The metaphorical expressions given as illustrations of these conceptual metaphors are highly conventionalized; that is, they are well worn or even clichéd. In fact, most speakers would not even notice that they use metaphor when they use the expression defend in connection with arguments, construct in connection with theories, and go our separate ways in connection with love. For native speakers of English, these are some of the most ordinary and natural ways to talk about these subject matters. Conventional conceptual metaphors, such as argument is war, love is a journey, and theories are buildings, are deeply entrenched ways of thinking about or understanding an abstract domain, while conventional metaphorical linguistic expressions are well worn, clichéd ways of talking about abstract domains.

For the purposes of a clearer exposition, conceptual metaphors can be classified according to the cognitive functions that they perform. On this basis, three general kinds of conceptual metaphor have been distinguished: structural, ontological, and orientation. These kinds of metaphor often coincide in particular cases. They are (a) structural metaphor, (b) ontological metaphor and (c) oriental metaphor. Structural metaphor concern to understand time in terms of some basic elements: physical objects, their locations, and their motion. There is a background condition that applies to this way of understanding.
For example time passing is an observer's motion over a landscape.

The time is motion metaphor (as specified in the mappings and the differences in the two versions) accounts for a large number of linguistic metaphors in English. The mappings not only explain why the particular expressions mean what they do but also provide a basic overall structure, hence understanding, for our notion of time. Without the metaphor it would be difficult to imagine what our concept of time would be. Most structural metaphors provide this kind of structuring and understanding for their target concepts.

Ontological metaphor provides much less cognitive structuring for target concepts than structural ones do. (Ontology is a branch of philosophy that has to do with the nature of existence.) Their cognitive job seems to be to "merely" give a new ontological status to general categories of abstract target concepts and to bring about new abstract entities. It means that people deliberate their experiences in terms of objects, substances, and containers, in general, without specifying exactly what kind of object, substance, or container is meant. For example, speakers do not really know what the mind is, but they conceive of it as an object (note the use of the word what in the first part of this sentence). This way they can attempt to understand more about it. In general, ontological metaphors enable us to see more sharply delineated structure where there is very little or none.

Ontological metaphor can be understood as personification in its form. In personification, human qualities are given to nonhuman entities. Personification is common in literature, but it also abounds in everyday discourse, as the examples below show:

His theory explained to me the behaviour of chickens raised in factories

Life has cheated me

Inflation is eating up our profits

Cancer finally caught up with him

The computer went dead on me

Theory, life, inflation, cancer, and computer are not humans, but they are given qualities of human beings, such as explaining, cheating, eating, catching up, and dying. Personification makes use of one of the best source domains we have ourselves. In personifying nonhumans as humans, it can begin to understand them a little better.

Oriental metaphor provides even less conceptual structure for target concepts than ontological ones. Their cognitive job, instead, is to 
make a set of target concepts coherent in our conceptual system. The name "orientation metaphor" derives from the fact that most metaphors that serve this function have to do with basic human spatial orientations, such as up-down, centre-periphery, and the like. It would perhaps be more appropriate to call this type of conceptual metaphor "coherence metaphor," which would be more in line with the cognitive function these metaphors perform. By "coherence," we simply mean that certain target concepts tend to be conceptualized in a uniform manner. For example, all the following concepts are characterized by an "upward" orientation, while their "opposites" receive a "downward" orientation.

More is up; less is down: Speak up, please. Keep your voice down, please.

Healthy is up; sick is down: Lazarus rose from the dead. He fell ill.

Conscious is up; unconscious is down: Wake up.

He sank into a coma.

Control is up; lack of control is down: I'm on top of the situation. He is under my control.

Happy is up; sad is down: I'm feeling up today. He's really low these days.

Virtue is up; lack of virtue is down: She's an upstanding citizen. That was a low-down thing to do.

Rational is up; no rational is down: The discussion fell to an emotional level. He couldn't rise above his emotions.

Nature of metaphor is based on both knowledge and image. Most of the metaphors are based on human basic knowledge of concepts. In them, basic knowledge structures constituted by some basic elements are mapped from a source to a target. In another kind of conceptual metaphor that can be called image-schema metaphor, however, it is not conceptual elements of knowledge (like traveller, destination, and obstacles in the case of journey) that get mapped from a source to a target, but conceptual elements of image-schemas.

These phrases have to do with events and states such as losing consciousness, lack of attention, something breaking down, death, and absence of something. All of them indicate a negative state of affairs. More important for the discussion of image-schema metaphors is that they map relatively little from source to target. As the name implies, metaphors of this kind have source domains that have skeletal image-schemas, such as the one associated with out. By contrast, structural metaphors are rich in knowledge structure and provide a relatively rich set of mappings between source and target.
Image-schemas are not limited to spatial relations, such as "in-out." There are many other "schemas" that play a role in our metaphorical understanding of the world. These basic imageschemas derive from our interactions with the world: Human explore physical objects by contact with them; people experience ourselves and other objects as containers with other objects in them or outside of them; they move around the world; they experience physical forces affecting them; and they also try to resist these forces, such as when they walk against the wind. Interactions such as these occur repeatedly in human experience. These basic physical experiences give rise to what are called image schemas, and the image-schemas structure many of our abstract concepts metaphorically.

An interesting property of image-schemas is that they can serve as the basis of other concepts. Thus, for instance, the motion schema underlies the concept of a journey. The motion schema has the parts, initial point, movement, and end point, to which correspond in journeys the point of departure, the travel, and the destination. In this way, most apparently non image-schematic concepts (such as journey) seem to have an imageschematic basis. The target domains of many structural metaphors can then be seen as image schematically structured by their source (such as life is a journey). Other kinds of image-based conceptual metaphors are richer in imagistic detail but do not employ image schemas. We can call them image metaphors.

Metaphors in Hasan Tiro's speech were used to persuade Sumatera people to maintain their property from the other nation through join with Aceh Merdeka. He conveyed the metaphors by using source domains which is easier to understand by the audiences. His ability to use the common source domain in building communication was proved by numerous followers in Aceh and Sumatera.

\section{CONCLUSION}

The different of conceptual in metaphors is determined to the way of speakers producing the concept. Politicians deliver their thought and ideas through speech. The using metaphor in a speech is necessary in order to persuade their listeners. The way of speakers in delivering their speech is able to The using of metaphor for social and political conceptualization has been acknowledged in much more positive terms. Politicians often use metaphor 
in their speech to wrap their point by using or comparing one object to the other which have similar characteristics.

As politicians, it is important to the leaders to produce language that persuade their audience. They can use metaphor to convey the meaning that related to the culture of theirs. Thus, they could be known as phenomenal leader. Hasan Tiro used Conventional metaphor and Ontological metaphor in his speech to make the audiences understand his intension and persuade them to join with him in building Sumatera country. In order to attract and persuade the listeners/audiences. The metaphors should be suitable to the social context of the listeners/audience. For the lecturers who teach language, should provide a lot information in semantic field and discourse. In addition, they also should enrich it through translation.

The metaphors should be suitable to the social context of the listeners/audience. For the lecturers who teach language, should provide a lot information in semantic field and discourse. In addition, they also should enrich it through translation because the metaphors is arbitrary. For the other researchers, the information of Hasan Tiro speech based on linguistic needs more deeper research from the other field to complete it. It is suggested to do more research about metaphor in Hasan Tiro speech as a recommended that the students of literature to analyze this and also the students of anthropology to study based on culture.

\section{REFERENCES}

Bogdan and Biklen (1992) Qualitative Research for Education. Needham Heights: Allyn and Bacon.

Duranti, A. (2016) Anthropology of Intentions: Language in a World of Others. Cambridge: Cambridge University Press.

Kovecses, Z. (2010) Metaphor in a Practical Introduction. Oxford: University Press.

Lakoff, G. and Johnson (2003) Metaphors We Live By. Chicago: University of Chicago Press.

Lubis, T. (2016) 'Metaphors in Acehnese Literature Work', in Kongres Internasional Masyarakat Linguistik Indonesia (KIMLI) 2016. Bali: Masyarakat Linguistik Indonesia, pp. 861-864. doi: 10.17605/OSF.IO/GNAKM.

Lubis, T. (2017) 'Indeksikalitas dalam Perspektif Antropolinguistik', in Seminar Antarbangsa Kajian Linguistik dan Kearifan Lokal. Medan: Sekolah Pascasarjana USU Kerja Sama dengan Persatuan Linguistik, pp. 128-134. doi: 10.31227/osf.io/dwa7p.

Marpaung, S. (2011) Metaphor in Barack Obama's Speeches. Universitas Negeri Medan.
Moreno, M. (2008) Metaphors in Hugo Chávez's Political Discourse: Conceptualizing Nation, Revolution, and Opposition. City University of New York.

Newmark, P. (1988) A Textbook of Translation. London: Prentice Hall International.

Saragih, A. (2004) Metafora Tata Bahasa. Medan: Universitas Negeri Medan. 


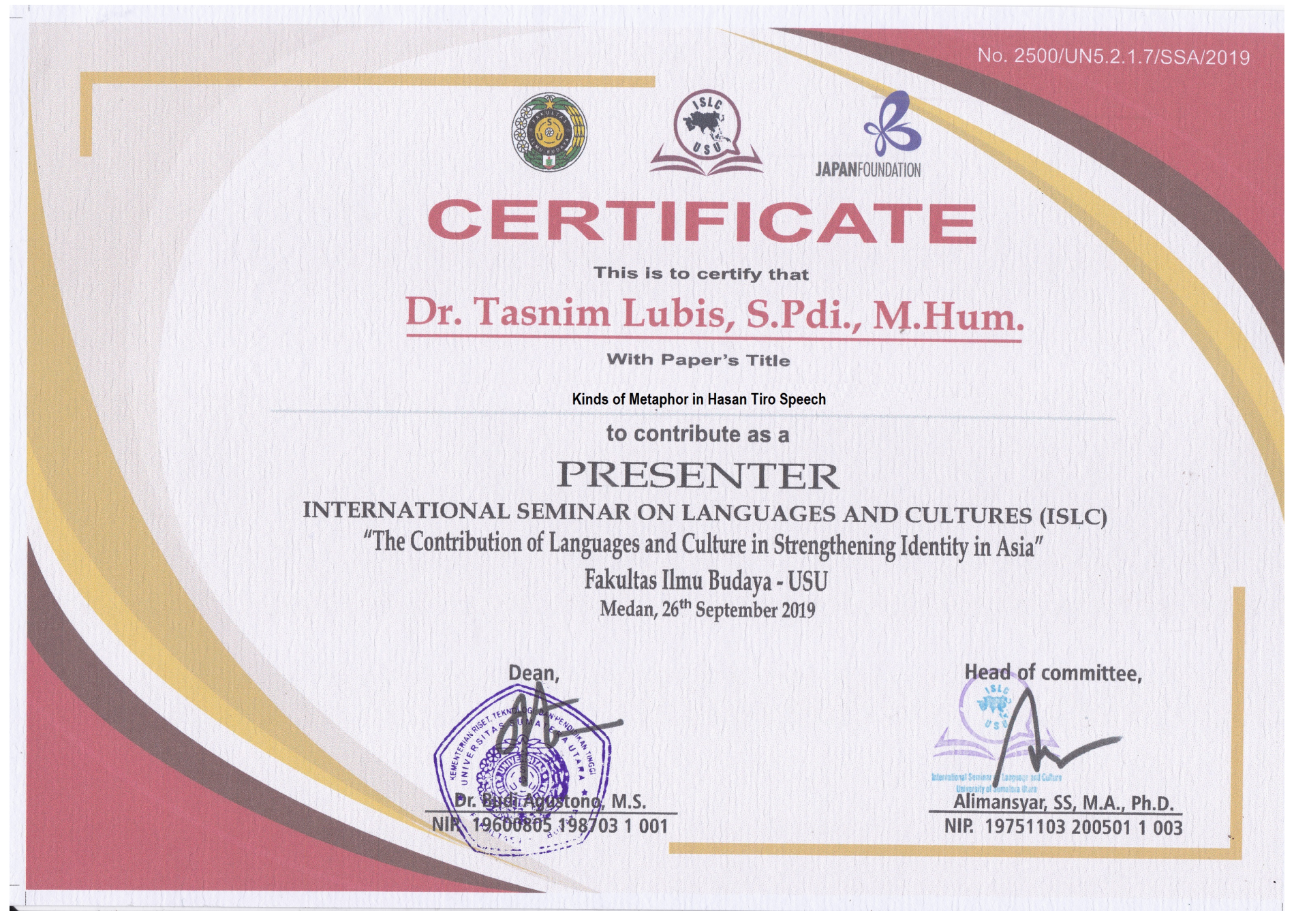

